\title{
Cimetidine in the management of the Zollinger-Ellison syndrome
}

\author{
W. LARKWORTHY \\ M.B., F.R.C.P.(Ed.), D.C.H., R.A.F.
}

\author{
H. L. DAVIES* \\ F.R.C.S., F.R.C.S.(Ed.)
}

RAF Hospital, Nocton Hall, Lincoln

\begin{abstract}
Summary
The first case of the Zollinger-Ellison syndrome treated from the outset continuously for more than a year with the histamine $\mathrm{H}_{2}$-receptor antagonist cimetidine is reported. Symptomatic response has been dramatic and sustained, marked endoscopic improvement has been observed with healing of oesophageal, gastric and stomal ulcers.
\end{abstract}

\section{Introduction}

In 1955, Zollinger and Ellison described the syndrome of recurrent peptic ulceration, gastric hypersecretion and an associated pancreatic tumour arising from non- $\beta$ cells of the islets of the pancreas. Gastric hypersecretion in this condition is due to the production of large quantities of gastrin or a gastrinlike hormone by the tumour. Histamine is a mediator in the parietal cell response to gastrin, the site of action being characterized as the $\mathbf{H}_{2}$-receptor. Histamine $\mathbf{H}_{2}$-receptor antagonists reduce gastric acid secretion by blocking the action of histamine at $\mathrm{H}_{2}$-receptor sites. The newest agent in this group, cimetidine, has been shown markedly to inhibit basal and stimulated gastric secretion in normal subjects (Burland et al., 1975a; Pounder et al., 1976) and in patients with duodenal ulceration (Pounder et al., 1975; Barbezat and Bank, 1977). Cimetidine appears to cause no significant side effects and to be free from the potential risk of agranulocytosis associated with its predecessor, metiamide (Burland et al., 1975b). Initial reports indicate that cimetidine promotes healing of duodenal ulcers (Blackwood et al., 1976; Bodemar and Walan, 1976; Gray et al., 1977).

\section{Case report}

A 70-year-old jeweller was admitted in December

\footnotetext{
* Present address: Wing Commander H. L. Davies, Caernarvonshire and Anglesey General Hospital, Bangor, Caernarvonshire.

Correspondence: Wing Commander W. Larkworthy, RAF Hospital, Nocton Hall, Nocton, Lincoln.
}

1975 complaining of dyspepsia, vomiting and diarrhoea which had occurred in increasingly severe episodes since he had undergone vagotomy and partial gastrectomy in 1971. The operation has been carried out because of persistent vomiting and radiological evidence of ulceration at the pyloro-duodenal region. At operation there was evidence of old ulceration of the first part of the duodenum and a tumour was found involving the pylorus and the first part of the duodenum along the anterior wall. It was thought that the tumour was a leiomyoma but histological appearances were considered to be those of a carcinoid tumour.

Endoscopy was undertaken soon after admission. The lower oesophagus was severely inflamed and multiple ulcers were present above the oesophagogastric junction. The gastric remnant was large with coarse nodular folds. The mucosa was uniformly inflamed and friable and a giant gastric ulcer involved much of the anterior wall of the stomach. There was also a deep penetrating ulcer of the posterior wall. The gastrectomy stoma was ulcerated throughout its circumference and there was ulceration of both efferent and afferent loops.

Basal gastric secretion studies showed a volume of $320 \mathrm{ml} / \mathrm{hr}$ and acid secretion of $28.8 \mathrm{mmol} / \mathrm{hr}$. In response to insulin-stimulated hypoglycaemia the volume was $330 \mathrm{ml} / \mathrm{hr}$ and acid secretion $39 \mathrm{mmol} /$ hr. Plasma gastrin levels were reported as $>120$ $\mathrm{pmol} / \mathrm{l}$ (normal range $0 \cdot 1-23 \mathrm{pmol} / \mathrm{l}$ ) and on dilution levels of 472 and $504 \mathrm{pmol} / \mathrm{l}$ were reported. An intravenous injection of secretin 2 units/ $\mathrm{kg}$ resulted in a rise of plasma gastrin from $640 \mathrm{pmol} / 1$ to $920 \mathrm{pmol} / 1$ within $15 \mathrm{~min}$.

In January 1976 the patient developed a melaena which required transfusion. Two weeks later, he suffered a partial thickness myocardial infarct. A supply of cimetidine was obtained in February 1976, by which time he was experiencing almost continuous symptoms of nausea, epigastric and lower chest pain, with intermittent vomiting and watery diarrhoea. Treatment was started with oral cimetidine 
$200 \mathrm{mg}$ three times daily and $400 \mathrm{mg}$ at night. Within $20 \mathrm{~min}$ of taking the first tablet his symptoms disappeared and have not returned. Endoscopic review after treatment for a month showed remarkable improvement. The oesophagus showed mild inflammation but no ulceration, the gastric mucosa was diffusely reddened but coarse nodular folds were less evident. The giant gastric ulcer had healed and a small ulcer slough was seen on the posterior wall of the stomach.

The stoma appeared healthy but could not be examined adequately because of food residue. At endoscopy after 2 months treatment, the whole gastric mucosa appeared uniformly inflamed with a diffuse coarse black reticular appearance thought to be due to submucosal haemorrhages. Two months later when endoscopy was repeated, the gastric mucosa appeared healthy, mild inflammation surrounded the stoma and there was mild diffuse inflammation of the efferent loop. The patient has now been treated continuously for more than one year and the initial dose of cimetidine has not been changed. Endoscopic examination carried out on the anniversary of starting treatment showed no mucosal inflammation or ulceration whatsoever. The tumour block prepared in 1971 was available and fresh sections were made. The histological appearances were of an endocrine cell tumour consistent with a gastrinoma but immunological preparations for gastrin were negative owing to inappropriate fixation of the original biopsy material. Liver and pancreas scans were carried out and were normal.

Invasive investigation, laparotomy and further gastric surgery have been considered but rejected because the risks of surgery are high, the patient is now 70 years old, is, as far as he is concerned, in good health, and has suffered a myocardial infarction.

\section{Discussion}

The history suggests a gastrin-producing tumour, possibly in the pancreas or more probably a secondary tumour in the liver. That the original tumour lay outside the pancreas is of interest but is recognized. In a series reported by Howe (1965), $10 \%$ of tumours occurred in the duodenal wall and $2 \%$ as discrete adenoma of the pyloric region of the stomach. Carcinoid tumours are microscopically similar to gastrinoma and distinction may be possible only by immunological preparations for gastrin (Stremple, 1975).

The place of long term treatment with histamine $\mathrm{H}_{2}$-receptor antagonists in the management of cases of the Zollinger-Ellison syndrome will become clear as experience accumulates. In patients who are young or relatively young, provided the diagnosis has been made before any gastric surgery, total gastrectomy with tumour removal followed by monitoring of the serum gastrin levels would appear still to be the treatment of choice and a period of pre- $c$. operative treatment with a histamine $\mathrm{H}_{2}$-receptor antagonist would improve the patient's condition? and render the surgeon's task less difficult. However,

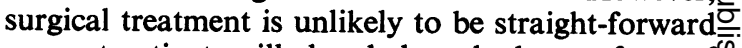
as most patients will already have had some form of gastric surgery and Wilson and Ellison (1966)尽 reported an associated survival of only $53 \%$ in patients who underwent total gastrectomy subse- quent to a lesser procedure. After 14 months' treatment there has been no indication to increase the $\vec{\omega}$

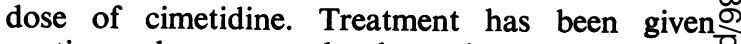
continuously, repeated absorption curves haveo shown some variability but effective blood levels $\exists$. have been reported on each occasion.

\section{Acknowledgments}

We are grateful to the Director General of Medical Services, Royal Air Force, for permission to publish this paper. The 6 patient was referred by Dr E. P. Morley of the Lincoln 을 County Hospital. Histological opinions were given by Professor Dawson of Nottingham University and Wing $\vec{\square}$ Commander I. Chorlton, Consultant Pathologist, Royal Air Force. We are also grateful to the clinical research group in the Research Institute of Smith Kline and French for their $\frac{\mathbb{D}}{3}$ advice and for providing the cimetidine tablets.

\section{References}

Barbezat, G.O. \& BANK, S. (1977) In: Cimetidine (Ed. W. L. Burland and M. A. Simkins), p. 110. Excer Medica, Amsterdam.

Blackwood, W.S., Maudgal, D.P., Pickard, R.G., LAWRENCE, D. \& NorThField, T.C. (1976) Cimetidine in duodenal ulcer, Lancet, ii, 174.

Bodemar, G. \& Walan, A. (1976) Cimetidine in the treat-ฉָ ment of duodenal and prepyloric ulcers, Lancet, ii, 161 .

Burland, W.L., Duncan, W.A.M., Hesselbo, T., Mills, $\stackrel{2}{\vec{t}}$ J.G., Sharpe, P.C., Haggie, S.J. \& Wyllie, J.H. (1975a) $\overrightarrow{\bar{\sigma}}$ Pharmacological evaluation of cimetidine, a new histamine 3 $\mathrm{H}_{2}$-receptor antagonist, in healthy man. British Journal of Clinical Pharmacology, 2, 481.

Burland, W.L., Sharpe, P.C., Colin-Jones, D.G., TurnBULL, P.R.G. \& Bowskill, P. (1975b) Reversal of meti-흠 amide-induced agranulocytosis during treatment with cimetidine. Lancet, ii, 1085.

Gray, G.R., McKenzie, I., Smith, I.S., Crean, G.P. \&

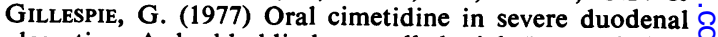
ulceration. A double-blind controlled trial. Lancet, i, 4.

Howe, C.T. (1965) Ulcerogenic tumour of the pancreas. Scottish Medical Journal, 10, 307.

Pounder, R.E., Williams, J.G., Milton-Thompson, G.J. \& MIsIEwICZ, J.J. (1975) 24-hour control of intragastric acidity by cimetidine in duodenal ulcer patients. Lancet, ii, 1069.

Pounder, R.E., Williams, J.G., Milton-Thompson, G.J. \& MisiewICZ, J.J. (1976) Effect of cimetidine on 24-hour $N$ intragastric acidity in normal subjects. Gut, 17, 133 .

STREMPLE, J.F. (1975) Gastrinomas: gastrin-producing $\omega$ tumours. Surgical Clinics of North America, 55, 303.

Wilson, S.D. \& Ellison, R.M. (1966) Survival in patients 6 treated by total gastrectomy. Annals of Surgery, 111, 787. $\frac{\mathrm{D}}{\mathrm{D}}$

Zollinger, R.M. \& Ellison, E.H. (1955) Primary peptic ulcerations of the jejunum associated with islet cell tumours of the pancreas. Annals of Surgery, 142, 709. 